\title{
Protective effects of stem bark of Harungana madgascariensis on the red blood cell membrane
}

\author{
Prosper Cabral Nya Biapa ${ }^{1}$, Horea Matei ${ }^{2}$, Ştefana Bâlici ${ }^{2}$, Julius Eyong Oben ${ }^{3}$ and Jeanne Yonkeu Ngogang ${ }^{4}$
}

\begin{abstract}
Background: Anemia is a condition that has multiple origins. One such origin is the destruction of red blood cells' (RBCs) membrane induced by free radicals. Treatment of anemia could therefore be enhanced by the use of free radicals' scavengers potentially found in some medicinal plants. In this study, the protective effect of Harungana madagascariensis on the RBCs' membrane physiology was investigated in vitro and in vivo.

Methods: In vitro hemolytic anemia was induced by incubation of fresh human RBCs with carbontetrachloride $\left(\mathrm{CCl}_{4}\right)$ in Olive oil (Oo). Relaxation times of protons excited at $20 \mathrm{MHz}$ (Carr-Purcell-Meiboom-Gill pulse sequence) in the absence or presence of paramagnetic $\mathrm{Mn}^{2+}$ ions ( $T_{2 i}$ for "extracellular" water and $T_{2 a}$ for "intracellular" water, respectively) were determined at several temperatures $\left(25-37^{\circ} \mathrm{C}\right)$ via Nuclear Magnetic Resonance (NMR) on a Bruker Minispec spectrometer. Water exchange times $\left(T_{e}\right)$ were consequently calculated using the Conlon-Outhred equation: $1 / T_{e}=\left(1 / T_{2 a}\right)-\left(1 / T_{2 i}\right)$. Morphological characteristics (mean cell volume, $\mathrm{V}$, and cell surface area, $\left.A\right)$ were determined by photonic microscopy and the RBCs' diffusional water permeability $\left(P_{d}\right)$ was calculated as $P_{d}=\left(1 / T_{e}\right)^{*}$ $\left(V_{a} / A\right)$, where $V_{a}$ is the aqueous volume in the RBC and is about 0.7 of the cell volume $(V)$. The activation energy of the diffusional process $\left(E_{a}\right)$ for the respective temperature range was estimated using the Arrhenius modified

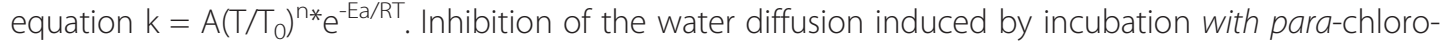
mercuribenzoic acid (PCMB) at 25,30 and $37^{\circ} \mathrm{C}$ was calculated as I(\%) $=\left[(\mathrm{Pd} \text { control }-\mathrm{Pd} \text { sample) } / \mathrm{Pd} \text { control }]^{*} 100\right.$. To investigate the protective influence of the extract on the RBC membrane, inhibition of the water permeability was evaluated on membranes pre-incubated with the Harungana madagascariensis extract. Male rats were used in in vivo investigations. Malondialdehyde (MDA) and cholesterol in the RBC membrane were estimated by induction of lipid peroxidation while the antioxidant properties of catalase (CAT) and superoxide dismutase (SOD) on the membrane were evaluated in regard to their antioxidant properties on the membrane.

Results: $T_{2 a}$ significantly decreased at each temperature. Te results were higher in both RBCs and RBCs + extract groups incubated with PCMB compared to non-incubated controls, but differences were not statistically significant. A high percentage $(73.81 \pm 7.22)$ of RBCs pre-incubated with the extract presented the regular biconcave shape. Inhibition by $\mathrm{PCMB}$ of the $\mathrm{RBCs}$ membrane water permeability was increased at $30^{\circ} \mathrm{C}$ and decreased in the presence of extract $\left(25^{\circ} \mathrm{C}\right.$ and $37^{\circ} \mathrm{C}$ ), while Ea decreased from $30.52 \pm 1.3 \mathrm{KJ} / \mathrm{mol}$ to $25.49 \pm 1.84 \mathrm{KJ} / \mathrm{mol}$. Presence of the Harungana madagascariensis extract normalized the SOD and CAT activities as well as the MDA and membrane cholesterol concentrations altered by the $\mathrm{CCl}_{4}$-induced oxidative stress.
\end{abstract}

Conclusion: Harungana madagascariensis could protect the RBCs' membrane through its antioxidative properties. Keywords: Anemia, Water permeability, NMR, Harungana madagascariensis

\footnotetext{
* Correspondence: hmatei@umfcluj.ro

2Department of Cell and Molecular Biology, "Iuliu Hațieganu" University of

Medicine and Pharmacy, Cluj-Napoca, Romania

Full list of author information is available at the end of the article
} 


\section{Background}

The erythrocyte membranes refer to the lipid bilayer (phospholipids and cholesterol) containing the transmembrane proteins of the cytoskeleton and an assembly of proteins regularly interconnected [1,2]. Multiple proteins make up the erythrocyte membrane cytoskeleton, which interacts with both the lipid bilayer and transmembrane proteins to give the red blood cell its characteristics strength and integrity of major intrinsic proteins. Ankyrin provides the primary linkage between $\alpha$ - and $\beta$-spectrin tetramers and the cytoplasmic domain of the major integral protein band 3, a relationship enhanced by interactions with protein 4.2 . The junctional complexes formed by spectrin tetramers and their interaction with tropomyosin, adducin, actin and other proteins ensure the stability between the cytoskeleton and the lipid bilayer [2]. In some abnormal conditions of the RBCs membrane, such as hereditary spherocytosis (HS), hereditary elliptocytosis (HE), hereditary pyropoikilocytosis (HPP) or the Southeast Asian Ovalocytosis (SAO), these membrane proteins are usually defective because of their specific inherited gene mutations [3]. The high permeability of RBC membranes is due to the presence of water channel proteins called aquaporins (AQP) [4]. An important characteristic of RBCs' water diffusional permeability is its inhibition by the PCMB [5]. There are two basic strategies for measuring water exchange through the RBC membranes: the non-stationary method via volume changes and the stationary method using NMR techniques [6].

Self-administered drugs, auto-immunity, immunoallergy, parasitic and viral infections could also lead to oxidative stress and defective RBCs [7]. Oxidative stress results from an imbalance between the formation and neutralization of pro-oxidants [8,9]. It is well known that carbontetrachloride as well as phenylhydrazine induces RBC damages [10,11]. Cells have therefore developed antioxidant mechanisms to quench the free radicals but when the generation of free radicals exceeds the scavenging capacity of the cell, the excessive free radicals seek stability through electron sharing with biological macromolecules such as proteins, lipids and DNA. This is why in healthy human cells this process results in the induction of lipid peroxidation, which in turn leads to atherosclerosis, cardiovascular diseases, ageing and inflammatory diseases [12]. Free radicals are known to be scavenged by synthetic antioxidants, but this procedure can sometimes generate adverse side effects leading to carcinogenicity. Search for effective natural antioxidants has become crucial [13].

World Health Organization (WHO) encourages the use of medicinal plants in the treatment of diseases [14]. Harungana madagascariensis is a medicinal plant traditionally used to fight anemia in Cameroon. Previous works have shown the anti-malarial activity of its methanolic extract [15]. Harunganin, harongin anthrone and 1,7-dihydroxyxanthone were isolated from the stem bark of this plant and their structures were elucidated by spectroscopic analysis [16]. Preceding works conducted in our laboratory included the phytochemical screening and in vitro antioxidant properties of the hydroethanolic bark extract as well as the in vivo anti-anemic activity of the same extract after the induction of hemolytic anemia in rats using phenylhydrazine (PHZ) $[17,18]$. In this study, we will further investigate the protective properties of the hydro-ethanolic bark extract of Harungana madagascariensis on the RBCs' membrane physiology.

\section{Methods}

\section{Animals}

The scientific committee of the University of Yaoundé I and the Cameroon National Ethics Committee approved the experimental procedures. Male rats $(200 \mathrm{~g})$ maintained on a $12 \mathrm{~h}$ light/dark cycle at room temperature $\left(26^{\circ} \mathrm{C}\right)$ with a relative humidity of $25 \%$ were allowed free access to water and food (made-up with maize, fish, salt, vitamins, soybean and oil).

\section{Plant material}

The stem bark of Harungana madagascariensis, from the family of Hypericaceae, has been collected in OkolaYaounde, in January 2010. The plant has been authenticated at the National Herbarium of Cameroon in Yaounde (Voucher specimen № 4224 HNC).

\section{Extraction}

After being washed and dried at room temperature, the collected plant was powdered and sieved. $100 \mathrm{~g}$ were soaked for about 48 hours in 2 litres of water - ethanol mixture (1:1 ratio) and then the suspension was filtered. Remaining residues were re-extracted as shown above. The total filtrate was concentrated using a rotary evaporator (Heidolph WB 2000). Water was further evaporated in an oven at $50^{\circ} \mathrm{C}$, giving $45 \%$ as yield of extraction. This procedure was chosen according to previous works with this extract $[17,18]$.

\section{Blood sample collection}

A fresh blood sample of a healthy 34 years old Cameroonian was used after informed consent from the subject was obtained. The procedure was approved by the ethics committee of the University of Medicine and Pharmacy in Cluj-Napoca, Romania. $20 \mathrm{~mL}$ of blood collected on Ethylenediaminetetraacetic acid (EDTA) at $4^{\circ} \mathrm{C}$ in the Neuro-Pediatric Clinic Center in Cluj-Napoca, Romania were used for the in vitro experiments. 


\section{In vitro experiments}

\section{Purification of red blood cells}

The method described by Benga et al. was used [19]. Briefly, from the blood sample refrigerated immediately after collection, RBCs have been isolated by three consecutive centrifugations followed by washings in medium $\mathrm{S}\left(150 \mathrm{mM} . \mathrm{L}^{-1} \mathrm{NaCl}, 5.5 \mathrm{mM} . \mathrm{L}^{-1}\right.$ glucose, $5 \mathrm{mM}^{*} \mathrm{~L}^{-1}$ HEPES, pH 7.4).

\section{Morphological measurements of RBCs Experiment}

Washed RBCs membranes' damage was induced using $\mathrm{CCl}_{4}$ in Oo. Many groups have been formed against the washed RBCs control (Table 1A). The $100 \mathrm{mM}$ PCMB solution was made up by mixing 0.035716 g PCMB with $300 \mu \mathrm{L}$ of $1 \mathrm{M} \mathrm{NaOH}$. After homogenization wash buffer (WB) was added up to $1 \mathrm{~mL}$. The photosensible solution was kept at $4^{\circ} \mathrm{C}$ covered in aluminium sheet until

\section{Table 1 Experimental groups for the morphological measurements of RBCs, the RBCs water permeability and the in vivo study of the extract against the oxidative stress}

Groups Experiment

A- Experimental groups for the morphological measurements of RBCs

\begin{tabular}{|c|c|}
\hline 1 & $\begin{array}{l}\text { RBCs }(600 \mu \mathrm{L})+\text { Extract in Oo } 1: 1(21 \mu \mathrm{L})+\text { WB,Prein } 37^{\circ} \mathrm{C}- \\
30 \mathrm{~min}, \ln 37^{\circ} \mathrm{C}-1 \mathrm{~h}\end{array}$ \\
\hline 2 & $\mathrm{RBCs}(600 \mu \mathrm{L})+\mathrm{CCl}_{4}(6 \mu \mathrm{L})($ in Oo $1: 1)+W B, \ln 37^{\circ} \mathrm{C}-1 \mathrm{~h}$ \\
\hline 3 & $\mathrm{RBCs}(600 \mu \mathrm{L})+\mathrm{CCl}_{4}(6 \mu \mathrm{L})+\mathrm{WB}, \ln 37^{\circ} \mathrm{C}-1 \mathrm{~h}$ \\
\hline 4 & $\begin{array}{l}\text { RBCs }(600 \mu \mathrm{L})+\text { Extract in Oo } 1: 1(21 \mu \mathrm{L})+\text { WB, Prein } 37^{\circ} \mathrm{C} \text { - } \\
30 \mathrm{~min}, \mathrm{CCl}_{4}(6 \mu \mathrm{L})(\text { in Oo } 1: 1), \ln 37^{\circ} \mathrm{C}-1 \mathrm{~h}\end{array}$ \\
\hline 5 & $\mathrm{RBCs}(600 \mu \mathrm{L})+\mathrm{WB}+\mathrm{PCMB} 1 \mathrm{M}(60 \mu \mathrm{L}), \ln 37^{\circ} \mathrm{C}-1 \mathrm{~h}$ \\
\hline 6 & $\begin{array}{l}\text { RBCs }(600 \mu \mathrm{L})+\text { Extract in Oo } 1: 1(21 \mu \mathrm{L})+\text { WB, Prein } 37^{\circ} \mathrm{C} \\
30 \mathrm{~min}, \mathrm{PCMB}(60 \mu \mathrm{L})(\text { in Oo } 1: 1), \ln 37^{\circ} \mathrm{C}-1 \mathrm{~h}\end{array}$ \\
\hline
\end{tabular}

B- Experimental groups for evaluating the RBCs water permeability in the presence or no of PCMB: NMR measurements

$1 \quad \operatorname{RBCs}(1200 \mu \mathrm{L})+\mathrm{WB}$, Prein $37^{\circ} \mathrm{C}-30 \mathrm{~min}, \mathrm{PCMB} 1 \mathrm{M}(60 \mu \mathrm{L})$, $\ln 37^{\circ} \mathrm{C}-1 \mathrm{~h}$

$2 \quad \operatorname{RBCs}(1200 \mu \mathrm{L})+$ extract in $\mathrm{Oo}, 1: 1(42 \mu \mathrm{L})+\mathrm{WB}, \ln 37^{\circ} \mathrm{C}-1 \mathrm{~h}$

$\mathrm{C}$ - Experimental groups for the in vivo study of the extract effects in relation with the lipid peroxidation and the oxidative stress on the RBCs

\begin{tabular}{|c|c|}
\hline 1 & Oo each day for 1 week ( $1 \mathrm{~mL} / 200 \mathrm{~g}$ bw/day) \\
\hline 2 & $\begin{array}{l}\text { Oo each day for } 1 \text { week }(1 \mathrm{~mL} / 200 \mathrm{~g} \text { bw/day), } \\
\mathrm{CCl}_{4}(2 \mathrm{~mL} / \mathrm{kg} \text { bw/day) in Oo on day } 7\end{array}$ \\
\hline 3 & $\begin{array}{l}\text { extract }\left(0.016 \mathrm{~g} / \mathrm{kg} \text { bw/day) } 1 \text { week and } \mathrm{CCL}_{4}\right. \\
(2 \mathrm{~mL} / \mathrm{kg} \text { bw/day) in the Oo on day } 7\end{array}$ \\
\hline 4 & $\begin{array}{l}\text { extract }\left(0.032 \mathrm{~g} / \mathrm{kg} \text { bw/day) } 1 \text { week and } \mathrm{CCl}_{4}\right. \\
(2 \mathrm{~mL} / \mathrm{kg} \text { bw/day) in the Oo on day } 7\end{array}$ \\
\hline 5 & $\begin{array}{l}\text { extract }(0.064 \mathrm{~g} / \mathrm{kg} \text { bw } / \text { day }) 1 \text { week and } \mathrm{CCl}_{4} \\
(2 \mathrm{~mL} / \mathrm{kg} \text { bw/day }) \text { in the Oo on day } 7\end{array}$ \\
\hline
\end{tabular}

$\mathrm{WB}=$ washed buffer, Prein = pre-incubation, $\mathrm{In}=$ incubation, Oo: Olive oil, The final volume of $6 \mathrm{~mL}$ in each tube was completed with wash buffer. The extract volume $(0.064 \mathrm{~g}$ of extract / $\mathrm{kg} \mathrm{bw})$ prepared with Oo $(1: 1, \mathrm{~m} / \mathrm{v}$ according to previous work) was calculated for a final $\mathrm{CCl}_{4}$ or $\mathrm{PCMB}$ tube concentration of $1 \mathrm{mM}$. use. Samples containing $600 \mu \mathrm{L}$ RBCs pre-incubated with extract or $\mathrm{CCl}_{4}, 60 \mu \mathrm{L}$ PCMB $100 \mathrm{mM}$ and $5.34 \mathrm{~mL} \mathrm{WB}$ (final PCMB concentration $1 \mathrm{mM}$ ) were incubated for $1 \mathrm{~h}$ at $37^{\circ} \mathrm{C}$ under continuous stirring. After incubation, each sample was washed 3 times.

\section{Measurements of RBCs}

For the estimation of RBC cells' number per $\mathrm{mm}^{3}(\mathrm{~N})$, $16 \mu \mathrm{L}$ of RBC: bovine serum albumin (BSA) $0.5 \%(1: 1)$ were diluted in $10 \mathrm{ml} \mathrm{WB}$ and gently homogenized. A drop of the solution was placed on the Thoma slide and covered with thin glass coverslip so that refraction rings became apparent. The slide was examined under a Nikon Eclipse 80i microscope with a color video camera and the number of RBC cells $(\mathrm{N})$ entirely placed within 16 large (256 small) grid squares were counted. For determining the hematocrit (Ht \%) the RBC:BSA 0,5\% (1:1) suspension was drawn into three capillaries and sealed, then centrifuged 10 minutes on a Hawksley microcentrifuge. The sedimented hematocrit (\%) was measured on the Hawksley scale and expressed as mean value of the three capillary samples. For diameter (D) measurements $5 \mu \mathrm{L}$ of the RBC:BSA 0,5\% (1:1) suspension were dropped in a thin BSA $0.5 \%$ layer on a glass slide and homogenized, then the area was delimited with a thin nylon thread, sealed with a glass coverslip and examined under the Nikon Eclipse 80i microscope. Cell volume (V) in $\mathrm{mm}^{3}$ was estimated as $\mathrm{V}=\mathrm{Ht}^{*} 10 / \mathrm{N}$. The cell surface was derived from the formula: $S=4 V / D+\Lambda D^{2} / 2$.

\section{RBCs water permeability}

The method for the RBCs water permeability assessment has been previously described $[6,20]$.

\section{Washed RBCs treatments and NMR measurements}

Washed RBCs were treated in the presence and absence of the PCMB inhibitor as presented in Table 1B. The fresh $\mathrm{PCMB}$ solution was prepared as above and RBCs were washed 3 times with $\mathrm{WB}$ and then centrifuged. The incubated washed RBCs (Table 1B) were split prior to being subjected to NMR. For the first part, used to determine longitudinal relaxation times of protons excited at $20 \mathrm{MHz}$ (Carr-Purcell-Meiboom-Gill pulse sequence) on a Bruker Minispec spectrometer [6,20] in the presence of paramagnetic $\mathrm{Mn}^{2+}$ ions $\left(T_{2 a}\right.$ for "extracellular" water), the NMR tube was formed by gently mixing $200 \mu \mathrm{L}$ of washed RBCs with $200 \mu \mathrm{L}$ BSA $0.5 \%$ in WB and $200 \mu \mathrm{L}$ of doping solution containing $40 \mathrm{mM}$ $\mathrm{MnCl}_{2}$ and $100 \mathrm{mM} \mathrm{NaCl}$. The second part was further centrifuged for $1 \mathrm{~h}$ at 50,000 g and was used (washed RBCs only) to determine ${ }^{1} \mathrm{H}^{+}$transversal relaxation time $\left(T_{2 i}\right.$ for "intracellular" water). The thermostat was progressively set for temperatures of $25^{\circ} \mathrm{C}, 30^{\circ} \mathrm{C}$ and $37^{\circ} \mathrm{C}$ and $T_{2 i}$ and $T_{2 a}$ measurements recorded. Water 
exchange times $\left(\mathrm{T}_{\mathrm{e}}\right)$ were consequently calculated using the Conlon-Outhred equation: $1 / \mathrm{T}_{\mathrm{e}}=\left(1 / \mathrm{T}_{2 \mathrm{a}}\right)-\left(1 / \mathrm{T}_{2 \mathrm{i}}\right)$. Based on the exchange times and morfological determinants, RBCs' diffusional water permeability $\left(\mathrm{P}_{\mathrm{d}}\right)$ was calculated as $\mathrm{P}_{\mathrm{d}}=\left(1 / \mathrm{T}_{\mathrm{e}}\right) *\left(\mathrm{~V}_{\mathrm{a}} / \mathrm{A}\right)$. The activation energy of the diffusional process $\left(E_{a}\right)$ for the respective temperature range was estimated from experimental data using the Arrhenius modified equation $\mathrm{k}=\mathrm{A}\left(\mathrm{T} / \mathrm{T}_{0}\right)^{\mathrm{n}_{*}} \mathrm{e}^{-\mathrm{Ea} / \mathrm{RT}}$ that makes explicit the temperature dependence of the preexponential factor [5]. Inhibition of the water diffusion induced by incubation with $\mathrm{PCMB}$ at 25,30 and $37^{\circ} \mathrm{C}$ was calculated as I $(\%)=[(\mathrm{Pd}$ control $-\mathrm{Pd}$ sample $) / \mathrm{Pd}$ control] $\times 100$.

All NMR tests followed the same procedure, including the non-incubated washed RBCs used as controls.

\section{In vivo experiments on rats}

Table 1C illustrates different groups formed for this investigation. Olive oil was used as carrier for the $H$. madagascariensis hydroethanolic extract. $2 \mathrm{~mL} / \mathrm{kg}$ body weight (bw) of $\mathrm{CCl}_{4}$ in $\mathrm{Oo}$ (1:1) were given orally on the seventh day to induce lipid peroxidation. RBCs membrane's lipid extraction was conducted using the method described by Folch et al [21]. Briefly, the tissue (precipitate) was homogenized with chloroform/methanol (2/1) to a final volume 20 times the volume of the tissue sample. After dispersion, the whole mixture was stirred 15$20 \mathrm{~min}$ in an orbital shaker at room temperature. The homogenate was centrifuged at $3000 \mathrm{rpm}$ to recover the liquid phase. This process was repeated 2 times. The solvent was washed with $1 \% \mathrm{NaCl}(1: 1)$ solution. After stirring, the mixture was centrifuged at $2000 \mathrm{rpm}$ to separate the two phases. The upper phase was eliminated by siphoning and the methanol/water (1/1) mixture was added to the lower phase and centrifugated at $3000 \mathrm{rpm}$. The lower chloroform phase containing the lipid fraction was evaporated under vacuum in a rotary evaporator.

The extract's effect against lipid peroxidation was quantified by the MDA and membrane cholesterol levels [22,23]. $400 \mu \mathrm{L}$ of thiobarbituric acid (TBA) reagent (20\% trichloroacetic acid, $0.375 \%$ TBA, $0.01 \%$ BHT (Butyl-Hydroxy-Toluene) and $1 \mathrm{~N} \mathrm{HCl}$ ) was added to 100 $\mu \mathrm{L}$ of serum. The mixture was incubated $15 \mathrm{~min}$ in a boiling water bath. After cooling, the suspension was centrifuged at $3000 \mathrm{rpm}$ for 10 minutes. The supernatant was then separated and absorbance was measured at $532 \mathrm{~nm}$. The MDA concentration was determined by the specific absorbance coefficient $\left(1.34 \times 10^{5} \mathrm{~mol} / \mathrm{cm}^{3}\right)$.

The lipid extract obtained using Folch's method was diluted (1:10) with acetone-ethanol (1:1) mixture and centrifuged at $3400 \mathrm{rpm}$ for $20 \mathrm{~min}$. $0.4 \mathrm{~mL}$ of the mixture was diluted with $6 \mathrm{~mL} \mathrm{FeSO}_{4} .2 \mathrm{ml}$ of concentrated sulfuric acid were added and mixed thoroughly. After 10 min at rest, the absorbance of the solutions of the tube was read at $490 \mathrm{~nm}$. The standard cholesterol solution was treated in the same manner and all readings of the absorbance were performed against a blank consisting of $0.4 \mathrm{ml}$ acetone-ethanol mixture. The RBC membrane cholesterol was estimated as follows:

$$
\begin{aligned}
\text { RBCMembraneCholesterol }\left(\frac{m g}{\mu l}\right) & =\frac{\text { DOtest }}{\text { DOstd }} \times \text { StdConc } \\
& \times \text { DilutionFactor }
\end{aligned}
$$

The antioxidant activity of the extract on the RBCs membrane was also estimated by measuring CAT and SOD activities [24,25]. The measurement of total SOD activity was performed according to Misra and Fridovich method [25], based on the inhibition of epinephrine autoxidation. $0.2 \mathrm{~mL}$ distilled water and $2.5 \mathrm{~mL}$ sodium carbonate buffer $0.05 \mathrm{M}, \mathrm{pH} 10.2$.were added to the $0.3 \mathrm{ml}$ buffered epinephrine to initiate the reaction. The absorbance at $480 \mathrm{~nm}$ was read for $150 \mathrm{~s}$ at $30 \mathrm{~s}$ intervals against a blank made up of $2.5 \mathrm{~mL}$ buffer, $0.3 \mathrm{~mL}$ epinephrine and $0.2 \mathrm{~mL}$ distilled water. The following equation allowed the calculation of the SOD activity

$$
\begin{aligned}
\text { SOD }\left(\frac{\text { unit }}{m g} \text { proteins }\right) & =\frac{\text { SOD }(\text { unit } / m L)}{\operatorname{Proteins}(m g / m L)} \\
& \times \text { DilutionFactor }
\end{aligned}
$$

The evaluation of CAT activity was performed by mixing $2.5 \mathrm{~mL} \mathrm{H}_{2} \mathrm{O}_{2} 30 \mathrm{mM}$ with $0.5 \mathrm{~mL}$ hemolysate. The disappearance of peroxide with the absorbance decrease in $30 \mathrm{~s}$ steps for $90 \mathrm{~s}$ was followed spectrophotometrically at $240 \mathrm{~nm}$ against a blank made up with $3 \mathrm{~mL}$ $\mathrm{H}_{2} \mathrm{O}_{2}$. One unit decomposes one micromole of $\mathrm{H}_{2} \mathrm{O}_{2}$ per minute at $25^{\circ} \mathrm{C}$ and $\mathrm{pH} 7.0$ under the specified conditions.

$$
\begin{aligned}
\text { CAT }\left(\frac{\text { unit }}{m g} \text { proteins }\right) & =\frac{\Delta A / \mathrm{min} \times 30000 \text { units }}{40 \mathrm{~cm} / M \times m g \text { Proteins }} \\
& \times \text { DilutionFactor }
\end{aligned}
$$

\section{Results}

Figure $1 \mathrm{~B}$ to $1 \mathrm{~F}$ show pictures of RBCs in different conditions against Figure $1 \mathrm{~A}$ representing the nonincubated controls. It appears that the biconcave shape which characterizes the healthy RBCs is seen in Figure 1A controls as well as in Figure $1 \mathrm{~B}$, where RBCs were preincubated with the extract at $37^{\circ} \mathrm{C}$. In contrast, Figure $1 \mathrm{C}$ presented damaged $\mathrm{RBCs}$ when incubated with $\mathrm{CCl}_{4}$. Moreover, red color (hemolytic signs) has been physically observed in tubes containing the washed RBCs incubated with $\mathrm{CCl}_{4}$. Hemolysis was not that evident when Oo was added to $\mathrm{CCl}_{4}$ before incubation (Figure 1D). It is apparent from Figure $1 \mathrm{E}$ and $1 \mathrm{~F}$ that RBCs were less damaged when previously incubated with the extract before adding 


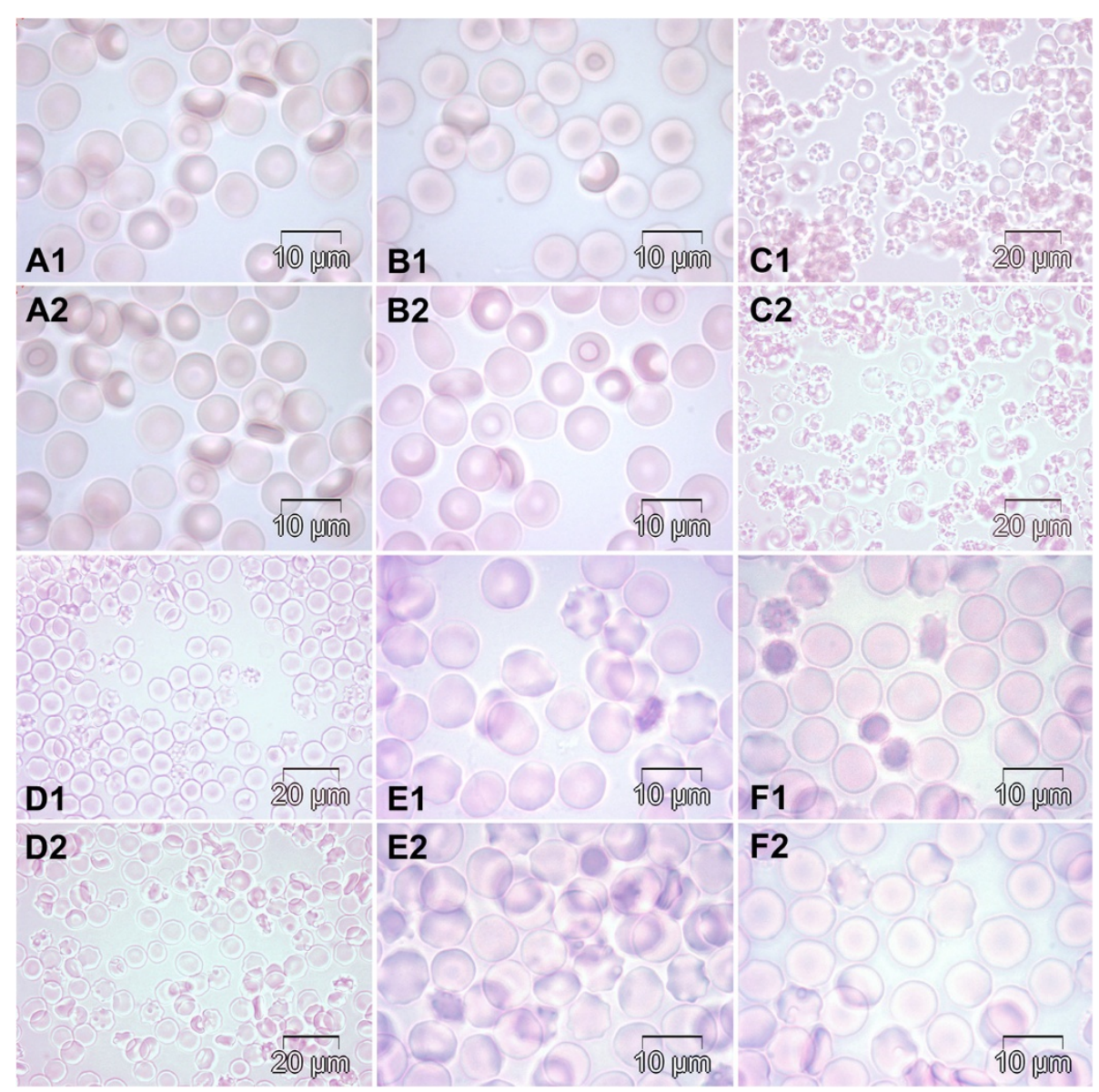

Figure 1 Bright field microscopy images presenting morphological changes of RBCs. Note the normal RBCs' morphology in the control group (panels A 1-2, 100X) and the degrees of morphological alteration seen in different experimental groups: RBCs pre-incubated with extract and incubated with Oo (panels B1-2, 100x); RBCs incubated with CCI4 (panels C1-2, 40x); RBCs incubated with CCI4+ Oo (panels D1-2, 40x); RBCs incubated with PCMB (panels E1-2, 100X) and RBCs pre-incubated with extract followed by incubation with PCMB (panels F1-2, 100X).

the PCMB. Nevertheless, some abnormalities appeared on several RBCs membranes.

Evaluated morphological parameters of the control RBCs were: $\mathrm{V}_{\mathrm{a}} / \mathrm{A}=0.46 \pm 0.11 \mu \mathrm{m}, \mathrm{Ht}(\%)=45.5 \pm 0.0 \%$, $\mathrm{N}=5.12 \pm 0.35$ million $/ \mathrm{mm}^{3}, \mathrm{~A}=135 \pm 4.8 \mu \mathrm{m}^{2}$ and $\mathrm{V}=88.9 \pm 0.0 \mu^{3}$. The percentages of healthy RBCs under multiple conditions are shown in Table 2. It appears from Table 2 that when RBCs were incubated with extract in Oo, $100 \%$ of these cells remained normal, while when incubated with $\mathrm{CCl}_{4}+\mathrm{Oo}$ or $\mathrm{CCl}_{4}$ exclusively, the RBCs became less healthy. The same observation was made when the RBCs were incubated either with $\mathrm{PCMB}$ or extract $\mathrm{Oo}+\mathrm{PCMB}$ respectively.

Table 3 and Figure 2 present the assessment of water diffusional exchange times $(T e)$ and water diffusional permeability $(P d)$, as well as the degree of inhibition induced by PCMB. When compared to the standard $P d(G)$, no noticeable difference was observed between the control Pd (B), Pd (EOo + PCMB) (D) and Pd (PCMB) (F) at the same temperature. A similar observation was made when comparing control Te and Te (EOo + PCMB) (C) or Te (PCMB) (E).

Also $\mathrm{Pd}(\mathrm{EOo}+\mathrm{PCMB})(\mathrm{D})$ at $30^{\circ} \mathrm{C}$ and $37^{\circ} \mathrm{C}$ is closer to control $P d$ and standard $P d$ values than $P d$ (PCMB) (F).

\section{Table 2 Percentage of Healthy Red Blood Cells under} different groups

\begin{tabular}{ll}
\hline Groups & Percentage of healthy RBCs \\
\hline $\mathrm{RBCs}+$ Extract $+\mathrm{Oo}+\mathrm{PCMB}$ & $73.81 \pm 7.22^{a}$ \\
\hline $\mathrm{RBCs}+\mathrm{PCMB}$ & $61.75 \pm 8.66^{\mathrm{b}}$ \\
\hline $\mathrm{RBCs}+\mathrm{CCl}_{4} \mathrm{Oo}$ & $9.76 \pm 0.00^{c}$ \\
\hline $\mathrm{RBCs}+\mathrm{Extract}_{\mathrm{Oo}}+\mathrm{CCl}_{4} \mathrm{Oo}$ & $27.28 \pm 053^{\mathrm{d}}$ \\
\hline $\mathrm{RBCs}+\mathrm{CCl}_{4}$ & $5.43 \pm 0.00^{\mathrm{e}}$ \\
\hline $\mathrm{RBCs}+$ Extract $+\mathrm{Oo}$ & $100.00 \pm 000^{f}$ \\
\hline
\end{tabular}

Oo = Olive oil; PCMB = Para - Chloromercuribenzoic acid; $\mathrm{CCl}_{4}=$ Carbon Tetrachloride; NP = total number of picture; One-way ANOVA followed by LSD. Values with different letters affected means significantly different at $\mathrm{P}<0.01$. 
Table 3 Water diffusion exchange times $(T e)$ and permeability rate $(P d)$ through the RBC membranes at 25,30 and $37^{\circ} \mathrm{C}$

\begin{tabular}{lccccccc}
\hline Goups Temp & A & B & C & D & E & F & G \\
\hline $25^{\circ} \mathrm{C}$ & $11.1 \pm 0.12$ & $4.2 \pm 0.15$ & $16.6 \pm 0.74$ & $2.8 \pm 0.66$ & $14.8 \pm 0.88$ & $3.1 \pm 0.74$ & $4.1 \pm 0.04$ \\
\hline $30^{\circ} \mathrm{C}$ & $9.3 \pm 0.16$ & $4.9 \pm 0.25$ & $13.6 \pm 1.02$ & $3.4 \pm 1.04$ & $14.6 \pm 0.6$ & $3.2 \pm 1.18$ & $4.8 \pm 0.04$ \\
\hline $37^{\circ} \mathrm{C}$ & $7.6 \pm 0.16$ & $6.1 \pm 0.25$ & $11.1 \pm 1.02$ & $4.9 \pm 1.04$ & $9.4 \pm 0.6$ & $4.2 \pm 1.18$ & $6.0 \pm 0.04$ \\
\hline
\end{tabular}

Paired Student's $t$ test.

$\mathrm{A}=\mathrm{Te}$ control $(\mathrm{ms}), \mathrm{B}=\mathrm{Pd}$ control $\left(\mathrm{x} 10^{3} \mathrm{~cm} / \mathrm{s}\right), \mathrm{C}=\mathrm{Te}(\mathrm{EOo}+\mathrm{PCMB})(\mathrm{ms})$,

$\mathrm{D}=\mathrm{Pd}(\mathrm{EOo}+\mathrm{PCMB})\left(\mathrm{x} 10^{3} \mathrm{~cm} / \mathrm{s}\right), \mathrm{E}=\mathrm{Te}(\mathrm{PCMB})(\mathrm{ms}), \mathrm{F}=\mathrm{Pd}(\mathrm{PCMB})\left(\mathrm{x} 10^{3} \mathrm{~cm} / \mathrm{s}\right)$,

$\mathrm{G}=\mathrm{Pd}$ standard $\left(\mathrm{x} 10^{3} \mathrm{~cm} / \mathrm{s}\right) ; \mathrm{EOo}=$ extract $+\mathrm{Oo}, \mathrm{PCMB}=$ Para-chloromercuribenzoic acid,

$T e=$ water diffusion exchange time; $P d=$ Diffusional permeability; Temp: temperature

At $30^{\circ} \mathrm{C}$ the percentage of inhibition for the water diffusional permeability of the PCMB-incubated RBCs was higher as compared to that of the extractpreincubated $\mathrm{PCMB}$-incubated $\mathrm{RBCs}$, while at $25^{\circ} \mathrm{C}$ and $37^{\circ} \mathrm{C}$ water diffusional permeability was higher for the extract-preincubated group not treated with PCMB. In addition, the $E a$ varied noticeably from $30.52 \pm 1.3 \mathrm{KJ} / \mathrm{mol}$ to $25.49 \pm 1.84 \mathrm{KJ} / \mathrm{mol}$ respectively.

The anti-peroxidative and antioxidant properties of the extract through the RBCs membrane are illustrated in Table 4. No significant difference was observed between controls' MDA concentration $(0.005 \mu \mathrm{mol} / \mathrm{g})$ and that of the extract dose-dependent groups with values varying between $0.005 \mu \mathrm{mol} / \mathrm{g}$ and $0.0052 \mu \mathrm{mol} / \mathrm{g}$, but significant difference was recorded when compared to the group that was treated with $\mathrm{CCl}_{4}+$ Oo.

Previous extract administration to rats was shown to stabilize the activities of CAT and SOD compared to controls that received Oo (Table 4).

\section{Discussion}

Free radicals are critically involved in various pathological conditions such as cancer, cardiovascular disorders, arthritis, inflammation and liver diseases [26]. Under normal physiological conditions, low concentrations of lipid peroxidation products are found in tissues and cells. In the presence of oxidative stress, more lipid peroxidation products such as MDA are formed in terminal phase due to cell damage and are frequently used as biomarkers for overall lipid peroxidation [27]. This process is illustrated by the increase of the MDA and membrane cholesterol concentrations due to the $\mathrm{CCl}_{4}$-induced oxidative stress on the RBCs membrane (Table 4). A reverse effect was observed when rats were previously given Harungana madagascariensis extracts. According to Hubbell and McConnell [28], the intoxication of experimental animals with carbon tetrachloride altered membrane structures with the increase of MDA and membrane cholesterol concentrations. Furthermore, the altered membrane structures generally lead to the disturbance of their fluidity associated with loss of enzymatic activity and decrease in transport capacity $[10,29]$. It becomes obvious that pre-treatment of experimental animals with Harungana madagascariensis extract could prevent the alteration of membrane fluidity. This was confirmed by the RBCs' morphology when pre-incubated and

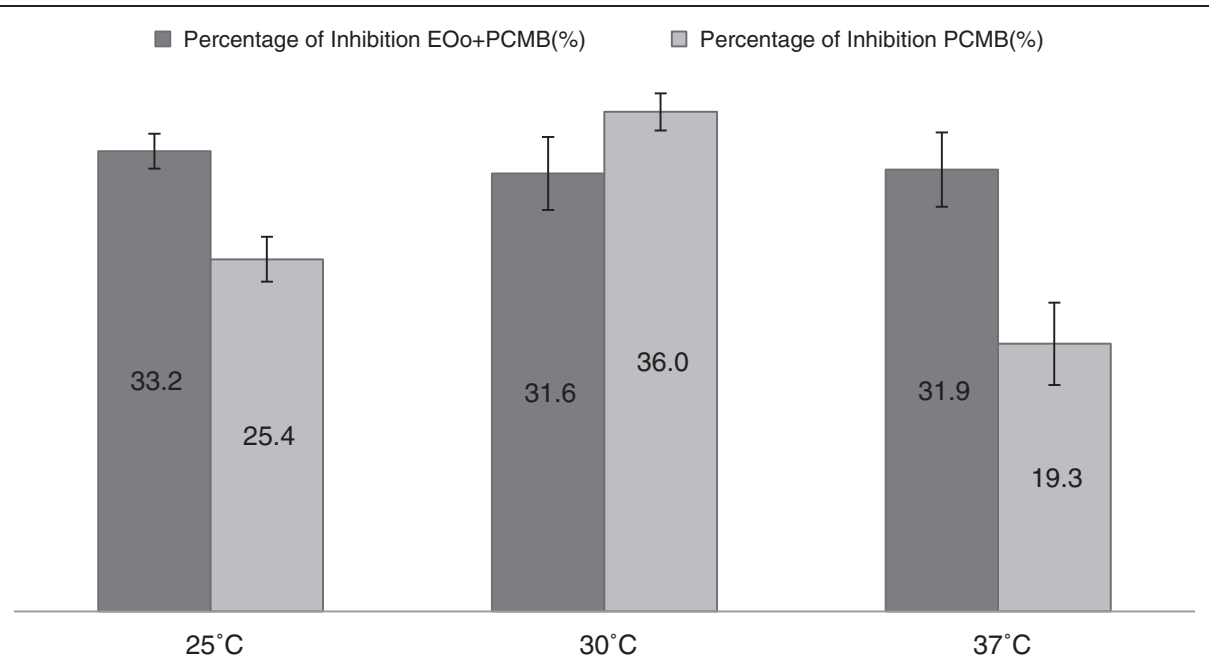

Figure 2 Percentage of inhibition for the water diffusion permeability induced by $\mathrm{PCMB}$. $\mathrm{EOO}=\mathrm{extract}+\mathrm{OO}, \mathrm{PCMB}=$ Para-chloromercuribenzoic acid, washed RBCs were used in each group. 
Table 4 Variation of RBCs' membrane cholesterol concentration, malondialdehyde, catalase and superoxide at different extracts' concentration

\begin{tabular}{|c|c|c|c|c|c|}
\hline Groups & Oo & $\mathrm{CCl} 4+\mathrm{Oo}$ & $0.016 \mathrm{~g} / \mathrm{kg}$ & $0.032 \mathrm{~g} / \mathrm{kg}$ & $0.064 \mathrm{~g} / \mathrm{kg}$ \\
\hline Catalase (U/L) & $47.90 \pm 1.20$ & $6.14 \pm 0.5^{*}$ & $49.60 \pm 1.80$ & $51.10 \pm 3.60$ & $48.40 \pm 1.80$ \\
\hline Superoxide dismutase $(\mathrm{U} / \mathrm{L})$ & $419.94 \pm 6.20$ & $169.33 \pm 7.50^{*}$ & $415.80 \pm 6.80$ & $430.30 \pm 9.60$ & $426.32 \pm 5.80$ \\
\hline Membrane cholesterol (mg/hL) & $5 \pm 0.20$ & $11 \pm 1.50^{*}$ & $7.5 \pm 0.80$ & $7.51 \pm 0.60$ & $7.49 \pm 0.80$ \\
\hline Malondialdehyde( $\mu \mathrm{mol} / \mathrm{g}$ protein) & $0.005 \pm 0.0$ & $0.01 \pm 0.0^{*}$ & $0.005 \pm 0.0$ & $0.0055 \pm 0.0$ & $0.0052 \pm 0.0$ \\
\hline
\end{tabular}

* significantly different at $P<0.05$. One-way ANOVA followed by LSD, Oo: Olive oil.

incubated with extract and $\mathrm{CCl}_{4}$ respectively (Figure $1 \mathrm{~B}$ and $1 F$ ), in addition to the elevated percentage of healthy red blood cells presented in Table 2. Similarly, previous works have shown that silymarin (flavonoid) as well as the extract of A. deliciosa reduced the level of $\mathrm{H}_{2} \mathrm{O}_{2}$ - induced stress through the stabilization of MDA concentration [30,31]. Thus Harungana madagascariensis could protect membrane from lipid peroxidation by inhibiting the free radicals' attack on bio-membranes. A lower RBCs damage observed on Figure 1D compared to Table 2 could be explained by the antioxidant properties of the Oo. Some abnormalities observed on many RBCs membranes (Figure $1 \mathrm{E}$ and $1 \mathrm{~F}$ ) could be referred to the aquaporin blocked by the PCMB [32]. The lesser destruction of RBCs showed in Figure 1F could be attributed to the protective action of the extract.

The function of antioxidant enzymes such as CAT and SOD is to protect cells from toxic reactive oxygen species [33]. In this study, we also determined the enzymatic antioxidant capacity in rat erythrocytes. The preadministration of the extract stabilizes the activities of CAT and SOD as compared to the control receiving Oo. This result could reinforce the protective effect of the extract on the RBCs membrane. It corroborates with previous works showing that pre-treatment of experimental animals with Hibiscus cannabinus extract prevented changes in the CAT and SOD activity as well as the decrease of the membrane cholesterol concentration [34]. It is known that alteration of bio-membranes can affect the membrane permeability [29]. Since an important characteristic of the water permeability of erythrocytes is its inhibition by sulfhydryl - binding mercurial reagents, the RBCs membrane permeability in the presence of $\mathrm{PCMB}$ was determined in order to investigate furthermore the extract activity through the membrane $[5,35]$. At $30^{\circ} \mathrm{C}$ (Figure 2), the RBCs' water permeability inhibition percentage induced by $\mathrm{PCMB}$ varies from $31.6 \%$ (RBCs + extract + PCMB) to 36\% (RBCs + PCMB). This could explain a diminished influence of the extract upon the RBC membranes in which the aquaporins are blocked by $\mathrm{PCMB}$ at $30^{\circ} \mathrm{C}$, which could be due to the $P d$ values of the group $\mathrm{RBCs}+$ extract + PCMB which vary from $3.4 \pm 1.04 \times 10^{3} \mathrm{~cm} / \mathrm{s}\left(30^{\circ} \mathrm{C}\right)$ to $4.9 \pm 1.04 \times 10^{3} \mathrm{~cm} / \mathrm{s}$ $\left(37^{\circ} \mathrm{C}\right)$ and are closer to the control than those of the group RBCs + PCMB varying from $3.2 \pm 1.18 \times 10^{3} \mathrm{~cm} / \mathrm{s}$ $\left(30^{\circ} \mathrm{C}\right)$ to $4.2 \pm 1.18 \times 10^{3} \mathrm{~cm} / \mathrm{s}\left(37^{\circ} \mathrm{C}\right)$.

Furthermore, results showed a remarkable decrease of the inhibition percentage at $25^{\circ} \mathrm{C}$ and $37^{\circ} \mathrm{C}$ when $\mathrm{RBCs}$ were pre-incubated with the extract, from $33.2 \%$ to $25.4 \%$ at $25^{\circ} \mathrm{C}$ and from $31.9 \%$ to $19.3 \%$ at $37^{\circ} \mathrm{C}$ respectively. In addition, $E a$ decreased from $30.52 \pm 1.3 \mathrm{KJ} / \mathrm{mol}$ to $25.49 \pm 1.84 \mathrm{KJ} / \mathrm{mol}$. When referring to Figure $1 \mathrm{~F}$, where RBCs were less damaged when previously incubated with the extract before adding the PCMB, inhibition percentages obtained could refer to the positive effect of the extract against the aquaporin blockage by $\mathrm{PCMB}$ at $25^{\circ} \mathrm{C}$ and $37^{\circ} \mathrm{C}$ since it is known that the PCMB molecule blocks the protein channel responsible for the RBC membrane water permeability [32]. These results correlate with data in Table 4 (variation of membrane cholesterol and MDA levels) explaining the protective effect of this extract on the RBCs membrane. According to Schafer and Andreoli, there are two components of the activation energy for water diffusion across the membrane [33]. One is the energy requirement for a water molecule to break the hydrogen bonds formed with neighboring molecules, while the other is the activation energy for water diffusion within the membrane. A low value of $E a$ for a molecule suggests that the molecule's transport pathway could involve a channel for water diffusion incorporated in membrane proteins with respect to the hydrophobic lipid bilayer. A low value of $E a$ is expected for RBCs with a high permeability and is directly related to the high number of water channels [34]. Subsequently, a slight although non significant increase was observed with the $P d(E O O+$ PCMB) (D) when compared to Pd (PCMB) (F) at $30^{\circ} \mathrm{C}$ and $37^{\circ} \mathrm{C}$. Pd (EOo + PCMB) (D) is closer to control Pd and standard Pd values than Pd (PCMB) (F).

Due to the high specificity techniques deployed results obtained by us were focused on certain parameters and this might be viewed as a limitation of this study. Future work needs to be conducted for further investigation of the mechanism of Harungana madagascariensis on the RBCs membrane using complementary techniques. Also the fingerprint of the plant metabolomics needs to be figured out using modern equipment/techniques such as high performance thin layer chromatography (HPTLC). 


\section{Conclusions}

According to previous works concerning the antioxidant as well as the antianemic properties of the extract of Harungana madagascariensis, it is clear through the present study that this extract could really protect the RBCs membrane and could thus strengthen the priority given to traditional medicine, helping people suffering from different type of anemia such as sickle cells disease.

\begin{abstract}
Abbreviations
AQP: Aquaporins; BSA: Bovine serum albumin; CAT: Catalase; $\mathrm{CCl}_{4}$ : Carbon tetrachloride; Ea: Activation energy; EDTA: Ethylene diamine tetra-acetic acid; HE: Hereditary ellipcytosis; HEPES: (4-(2-hydroxyethyl)-1-

piperazineethanesulfonic acid); HNC: National Herbarium of Cameroon; HPP: Hereditary pyropoikilocytosis; HPTLC: High performance thin layer chromatography; HS: Hereditary spherocytosis; MDA: Malondialdehyde; $\mathrm{MnCl}_{2}$ : Manganese (II) chloride; NaCl: Sodium chloride; NMR: Nuclear Magnetic Resonance; Oo: Olive oil; PCMB: Para- chloromercuribenzoic acid; Pd: Water Diffusional permeability; PHZ: Phenylhydrazine; RBC: Red blood cell; SAO: Southeast Asian Ovalocytosis; SOD: Superoxide dismutase; TBA: Thiobarbituric acid; $T_{2 a}:{ }^{1} \mathrm{H}^{+}$longitudinal relaxation time; $T_{2 i}:{ }^{1} \mathrm{H}^{+}$ transversal relaxation time; Te: Water exchange time; WHO: World Health Organization.
\end{abstract}

\section{Competing interests}

The authors declare that they have no competing interests.

\section{Authors' contributions}

BPC carried out the study, the statistical analysis and prepared the manuscript; BS prepared the RBCs samples for the NMR measurements, performed the NMR measurements and calculations and prepared various parts of the manuscript; HM, NYJ and JO co-directed and provided reagents. All the authors read and approved the final manuscript.

\section{Author details}

${ }^{1}$ Department of Biochemistry, Faculty of Sciences, University of Dschang, Dschang, Cameroon. ${ }^{2}$ Department of Cell and Molecular Biology, "Iuliu Hațieganu" University of Medicine and Pharmacy, Cluj-Napoca, Romania. ${ }^{3}$ Department of Biochemistry, Faculty of Sciences, University of Yaoundé I, Yaoundé I, Cameroon. ${ }^{4}$ Faculty of Medicine and Biomedical Sciences, University of Yaounde I, Yaounde I, Cameroon.

Received: 20 July 2012 Accepted: 1 May 2013

Published: 10 May 2013

\section{References}

1. Gallagher P, Et Lux S: Disorders of the erythrocyte membrane. In Nathan and Oski's hematology of infancy and childhood. Edited by Nathan D, Orkin S. Philadelphia: Elsevier-Saunders; 2003:560-684.

2. Discher DE, Et Carl P: New insights into red cell network structure, elasticity, and spectrin unfolding: a current review. Cell Mol Biol Lett 2001, 6:593-606.

3. Eber SW, Gonzalez JM, Lux ML, Scarpa AL, Tse T, Dornwell M, Herbers J: Ankyrin-1 mutations are a major cause of dominant and recessive hereditary spherocytosis. Nat Genet 1996, 13:214-218.

4. Agre P, Sasaki S, Chrispeels MJ: Aquaporins: a family of water channel proteins. Am J Physiol 1993, 265:F461.

5. Benga G, Popescu O, Pop VI: Water exchange through erythrocyte membranes: $p$-(Chloromercuribenzene)sulfonate inhibition of water diffusion in ghosts studied by a nuclear magnetic resonance technique. Biosci Rep 1985, 5:223-8.

6. Morariu W, Benga G: Evaluation of a nuclear magnetic resonance technique for the study of water exchange through erythrocyte membranes in normal and pathological subjects. Biochim Biophys Acto 1977, 469:301-310.

7. Danis M: Paludisme. In Urgences médico-chirurgicales de l'adulte. Edited by Carli P, Riou B, Viars P. Paris: Maison d'Edition Arnette; 1991:938-944.
8. Hazra B, Biswas S, Mandal N: Antioxidant and free radical scavenging activity of Spondias pinnata. Complem Altern Med 2008, 8:63-72.

9. Braca A, Sortino C, Politi M, Morelli I, Mendez J: Antioxidant activity of flavonoids from Licania licaniaeflora. J Ethanopharmacol 2002, 70:379-381.

10. Parasakthy K, Shanthy S, Deepalakshmi P, Niranjali S: The antioxidant effect of eugenol on $\mathrm{CCl}_{4}$-induced erythrocyte damage in rats. NutrBiochem 1996, 7:23-28.

11. Saowanee L, Upa K, Poungrat P, Veerapol K, Patchareewan P: Protective effects of quercetin against phenylhydrazine - induced vascular dysfunction and oxidative stress in rats. Food Chem Toxicol 2007, 45:448-455.

12. Chotimarkorn C, Benjakul S, Silalai N: Antioxidant components and properties of five long-grained rice bran extracts from commercial available cultivars in Thailand. Food Chem 2008, 111:636-641.

13. Adeolu AA, Florence OJ, Srinivas K: Assessment of the medicinal potential of the methanol extracts of the leaves and stems of Buddleja saligna. Complem Altern Med 2009, 9:21-28.

14. OMS: Traditional Complementary and Alternative Medicines and Therapies, Bureau Régional des Amériques de l'OMS/Organisation panaméricaine de la Santé. Washington DC: Groupe de travail OPS/OMS; 1999.

15. Ndjakou L, Vonthron-Sénécheau C, Fongang Soh R, Tantangmo F, Ngouela S, Kaiser M, Tsamo E, Anton R, Weniger B: $\mathrm{n}$ vitro antiprotozoal activities and cytotoxicity of some selected Cameroonian medicinal plants. J Etnopharm 2007, 111:8-12.

16. Nguyen VT, Debenedetti S, DeKimpe N: Phytochimie de la tige de Harungana madagascariensis. Tetrahedron Lett 2003, 44:41-99.

17. Biapa NP, Agbor GA, Oben JE, Ngogang JY: Phytochemical study and antioxidant properties of four anti-anaemic medicinal plants used in Cameroon. Afr J Trad CAM 2007, 4(4):495-500.

18. Biapa NP, Oben JE, Ngogang JY: Scavenging radical kinetic and Antianaemic Screening Properties of some Medicinal Plants used in Cameroon. JARNP 2011, 4(1):29-35.

19. Benga G, Frențescu L, Matei H, Tigan T: Comparative Nuclear Magnetic Resonance Studies of Water Permeability of Red Blood Cells from Maternal Venous Blood and Newborn Umbilical Cord Blood. Clin Chem Lab Med 2001, 39(7):606-611.

20. Conlon T, Outhred R: Water diffusion permeability of erythrocytes using an NMR technique. Biochem Biophys Acta 1972, 288:354-361.

21. Searcy RL: Bergquist: $A$ new colour reaction for the quantitation of serum cholesterol. Clin Chem Acta 1960, 5:192-199.

22. Folch J, Lees M, Stanley GHS: A simple method for the isolation and purification and total lipid from animal tissues. J Biol Chem 1957, 226:497-509.

23. Yagi K: A simple fluorometric assay for lipoperoxide in blood plasma. Biochem Med 1976, 15:212-216.

24. Beers JR, Sizer LW: A spectrophotometric method for measuring the breakdown of hydrogen peroxide. J Biol Chem 1952, 195:133-140.

25. Misra H, Et Fridovich I: Superoxide Dismutase: "Positive" Spectrophotometric Assays. Anal Biochem 1977, 79:553-560.

26. Martin MB, Et Butler RB: Understanding the basics of beta thalassemia major. Pediatr Nurs 1993, 19(2):143-145.

27. Neilsen F, Mikkelsen BB, Neilsen JB, Andersen HR, Grandjean P: Plasma malondialdehyde as biomarker for oxidative stress: reference interval and effects of life-style factors. Clin Chem 1997, 43:1209-1214.

28. Hubbell WL, McConnell HM: Molecular motion in spin-labeled phospholipids and membranes. J Am Chem Soc 1971, 93:314-326.

29. Cooper SA, Needle SE, Kruger GO: Comparative analgesic potency of aspirin and ibuprofen. J Oral Surg 1977, 35:898-903.

30. Kiruthiga PV, Shafreen RB, Pandian SK, Devi KP: Silymarin protection against major reactive oxygen species released by environmental toxins: exogenous $\mathrm{H}_{2} \mathrm{O}_{2}$ exposure in erythrocytes. Basic Clin Pharmacol Toxicol 2007, 100(6):414-419.

31. Bai X, Qiu A, Guan J, Shi Z: Antioxidant and protective effect of an oleanolic acid-enriched extract of $A$. deliciosa root on carbon tetrachloride- induced rat liver injury. Asia Pac J Clin Nutr 2007 16(1)):169-173.

32. Macey Rl: Transport of water and urea in red blood cells. Am J Physiol 1984, 246:195-203.

33. Matés JM, Segura JM, Pérez-Gómez C: Antioxidant enzymatic activities in human blood cells after an allergic reaction to pollen or house dust mite. Blood Cell Mol Dis 1999, 25(7):103-109. 
34. Agbor G: Phenylhydrazine, Carbon Tetrachloride, paracétamol induced toxicity in albino rats. Modulatory role of Hibiscus cannabinus (Linn). "Doctorat 3ème cycle". Thesis. Yaounde, Cameroon: Yaounde University Press; 2002.

35. Marcey RI, Farmer REL: Inhibition of water and solute permeability in human red blood cells. Biochim Biophys Acta 1970, 211:104-106.

doi:10.1186/1472-6882-13-98

Cite this article as: Biapa et al:: Protective effects of stem bark of Harungana madgascariensis on the red blood cell membrane. BMC Complementary and Alternative Medicine 2013 13:98.

\section{Submit your next manuscript to BioMed Central and take full advantage of:}

- Convenient online submission

- Thorough peer review

- No space constraints or color figure charges

- Immediate publication on acceptance

- Inclusion in PubMed, CAS, Scopus and Google Scholar

- Research which is freely available for redistribution 